African Crop Science Journal by African Crop Science Society is licensed under a Creative Commons Attribution 3.0 Uganda License. Based on a work at www.ajol.info/ and www.bioline.org.br/cs DOI: http://dx.doi.org/10.4314/acsj.v25i2.7

\title{
CONSTRAINTS TO CROP PRODUCTION AND ADAPTATION STRATEGIES OF SMALLHOLDER FARMERS IN SEMI-ARID CENTRAL AND WESTERN ZIMBABWE
}

\author{
V. MAKUVARO, S. WALKER ${ }^{1}$, A. MUNODAWAFA ${ }^{2}$, I. CHAGONDA, P. MASERE ${ }^{3}$, C. MUREWI $^{4}$ \\ and C. MUBAYA ${ }^{5}$ \\ Department of Agronomy, Midlands State University, P. Bag 9055, Gweru, Zimbabwe \\ ${ }^{1}$ Crops for the Future, The University of Nottingham Malaysia Campus, 43500 Semenyih, Selangor Darul \\ Ehsan, Malaysia \\ ${ }^{2}$ Department of Land and Water Resources Management, Midlands State University, P. Bag 9055, \\ Gweru, Zimbabwe \\ ${ }^{3}$ Institute of Science Systems, Durban University of Technology, South Africa \\ ${ }^{4}$ Department of Mathematics, Midlands State University, P. Bag 9055, Gweru, Zimbabwe \\ ${ }^{5}$ Directorate of Research and Resource Mobilization, Chinhoyi University of Technology, P. Bag 7724, \\ Chinhoyi, Zimbabwe \\ Corresponding author: makuvarov@msu.ac.zw,makuvarov@gmail.com
}

(Received 27 August, 2015; accepted 25 May, 2017)

\begin{abstract}
Smallholder farmer agricultural productivity in developing countries is limited by diverse biotic and abiotic constraints. They have, however, developed adaptive strategies to cope with some of these constraints, thereby strengthening their resilience to various stresses. The objective of this study was to establish crop production constraints faced by smallholder farmers in semi-arid Lower Gweru and Lupane areas of Zimbabwe, as well as coping and adaptation strategies used. Focus group discussions and structured interviews were used to collect data. High rainfall variability $(\mathrm{CV}=0.30)$ had the highest ranking (most important), followed by shortage of inputs collectively, from focus group discussions. Farmers adapted to rainfall variability mostly through choice of crop and planting dates, adjusting the levels of inputs (fertiliser in particular) they used, as well as by resorting to cropping in areas with a high water table. Sixty percent of the farmers in both communal areas experienced shortage of planting seed, while shortage of fertiliser was reported by 75 and $30 \%$ of the farmers in Lower Gweru and Lupane, respectively. Labour was a major constraint to 65 and $20 \%$ of the farmers in both locations, respectively; while draft power shortage affected 50 and $25 \%$ of the farmers. About $50 \%$ of the farmers in Lupane reported the problem of crop damage by elephants. The HIV and AIDs pandemic and poor soils were also reported during focus group discussions. Farmers coped with input shortages by hiring and sharing resources. They reduced damage from elephants by harvesting their crops early. The effect of HIV/AIDs weakened the labour force and some communities in the study areas helped affected families by working in their fields.
\end{abstract}

Key Words: Fertilisers, HIV, labour, seeds

\section{RÉSUMÉ}

La productivité agricole des petits paysans dans les pays en développement est limitéé par de diverses contraintes biotiques et abiotiques. Ils ont, cependant développé des strategies adaptatives pour faire face à ces contraintes, consolidant ainsi leur resilience aux divers stress. L'objectif de cette étude était d'établir les contraintes de la production agricole auxquelles font face les petits paysans dans les basses regions semi-arides de Gweru et 
Lupane au Zimbawé, ainsi que les strategies d'adaptation utilisées. Des discussions de groupes et des entretiens structurés ont été utlisés pour la collecte des données. La grande variabilité de pluies $(C V=0,30)$ a reçu le rang le plus élevé (le plus important); suivie de la pénurie générale d'intrants, selon les discussions de groupes. Les paysans se sont adaptés aux variabilitées de pluies à travers le choix des cultures et des dates de semis, en ajustant les niveaux d'intrants (engrais en particulier) qu'ils utilisaient, ainsi qu'en se recourant aux espaces de production avec une nappe phréatique affleurant la surface du sol. Soixante pourcent des paysans dans les deux zones communales rencontraient la pénurie des semences, alors que la penurie en engrais était rapportée par 75 et $30 \%$ des paysans de la basse Gweru et Lupane, respectivement. La main d'oeuvre a été une contrainte majeure pour 65 et $20 \%$ des paysans dans les deux regions, respectivement; tandis que le manque de traction animale a affecté 50 et $25 \%$ de producteurs. Environ 50\% de producteurs au Lupane ont rapporté le problème de destruction des plantes par les éléphants. La pendemie du VIH/SIDA et la pauvreté des sols ont aussi été rapportées pendant les discussions de groupes. Les producteurs se sont adaptés au manque d'intrants en loyant et en partageant leurs ressources. Ils ont réduit les dommages causés par les éléphants en récoltant de façon précoce leur cultures. Les effets du VIH/SIDA ont affaibli la force de la main d'oeuvre et certaines commautés dans les milieux d'étude ont aidé les familles affectées en travaillant dans leurs champs.

Mots Clés: Engrais, , VIH, main d'oeuvre, semences

\section{INTRODUCTION}

Zimbabwe's major economic backbone is agriculture which provides employment and livelihoods for approximately $70 \%$ of the population, $15-20 \%$ of the country's GDP and $40-50 \%$ of exports (Brewin et al., 2014). Similar to most developing countries of the world, smallholder agriculture in Zimbabwe is the major contributor to national food security (HLPE, 2013). Most of the smallholder farmers are directly dependent on utilisation of natural resources (Shiferaw, 2006, World Bank, 2008).

In terms of agricultural potential, most of the land area allocated to smallholder farmers in Zimbabwe lies in the marginal agroecological areas (Scoones et al., 2011). Thus the majority of smallholder farmers are located in climate risky environments, which are also often of poor soil fertility (Mashiringwani, 1983; Ncube et al., 2009) and where agriculture accounts for the most land use. The major farming system that has been adopted by these farmers is mixed farming based on cropping and animal rearing. Agriculture is largely rain fed, with few farmers practising irrigation on a relatively small scale.
Sustainability of smallholder agricultural productivity is threatened by both macro and micro-level constraints. Macro-level constraints include degradation of the natural base stimulated by heavy dependence on natural resources by the majority of the population in the country, as well as other natural and economic environmental factors such as climate change (Shiferaw, 2006; Mpandeli and Mapanya, 2014). However, there are also constraints of a micro-level nature that smallholder farmers continue to face. These include limited access to credit and information; unavailability and poor access to inputs (for example land, labour, seed and fertiliser) and the HIV_AIDs pandemic (Shiferaw, 2006; Mukasa et al., 2017).

To ensure food security there is need to develop sustainable strategies to address the various agricultural constraints that farmers face. This can be at farm, institutional and policy levels. The capacity of smallholder farmers to adapt to challenges they face in agricultural production is often limited by socio-economic and institutional factors (Munyani, 2012; Uddin et al., 2014).

It is encouraging to note that these farmers have certain levels of resilience developed over time. The aim of this study was to identify 
specific crop production constraints faced by farmers in semi-arid communal areas of Lower Gweru and Lupane in Zimbabwe and document coping/adaptation strategies developed by these farmers.

\section{MATERIALS AND METHODS}

Study area. The study was conducted in the communal areas of Lower Gweru and Lupane in Central and Western Zimbabwe. Two Wards were selected from each communal area for the study and these were Mdubiwa and Nyama Wards for Lower Gweru and Daluka and Menyezwa Wards for Lupane. In each ward, three villages were selected (Table 1).

Both areas are semi-arid, receiving relatively low rainfall $(450-700 \mathrm{~mm})$, with Lower Gweru (lying mostly in Natural Region III) being less marginal than Lupane, which lies in Natural Region IV. Soils in both Lower Gweru Wards are moderately shallow and range from course grained sands to sandy loams; while those in Lupane Wards are dominantly Kalahari sands (Makuvaro, 2014) of Aeolian origin (Nyamapfeni, 1991). The latter soils are highly infertile.

Research methods. A mixed research methods approach (Balnaves and Caputi, 2001; Flick, 2006) was used to collect data. The specific methods included use of secondary data (Bless and Higson-Smith, 2000), semistructured interviews with agricultural extension personnel, structured interviews with heads of households and Focus Group
Discussions (FGDs) with heads of households in selected villages (Table 1).

A total of 96 farmers, eight from each of the 12 villages were selected using random systematic sampling from a household list per village was obtained from the Department of Agricultural and Technical Services (AGRITEX). FGDs were also held with farmers from the same wards and villages, with five farmers randomly selected from each village, bringing the total number per discussion group to 15. A semi-structured questionnaire was developed and pre-tested for the household survey; while checklists were prepared for the FGDs and semistructured interviews.

In FGDs, farmers were grouped by ward and gender. Methods of data collection in FGDs included brainstorming discussion, matrix scoring and ordered ranking (Chambers, 1994; Sutherland, 1998). Four FGDs focusing on challenges faced in crop production were carried out in October 2008, when farmers were less busy in the fields. FGDs focusing on climate variability and change and household interviews to solicit information on constraints to crop productivity, as well as coping and adaptation strategies used by farmers, were conducted in January and February 2009. Timing of the activities was guided by availability of time on the part of both the researchers and farmers. For farmers, the best time was before they received the first effective rains (planting rains), which was normally around mid-November to midDecember. However, due to the relatively long

TABLE 1. List of Wards and villages from which household surveys and focus group discussions were conducted during 2008 and 2009

\begin{tabular}{lll}
\hline District & Ward & Villages \\
\hline Lower Gweru & $\begin{array}{l}\text { Mdubiwa } \\
\text { Nyama }\end{array}$ & $\begin{array}{l}\text { Mxotshwa, Nsukunengi and Madinga } \\
\text { Matonsi, Guduza and Siyabalandela }\end{array}$ \\
Lupane & $\begin{array}{l}\text { Daluka } \\
\text { Menyezwa }\end{array}$ & $\begin{array}{l}\text { Daluka, Strip road and Mafinyela } \\
\text { Menyezwa, Masenyane and Banda }\end{array}$ \\
\hline
\end{tabular}


time that was taken to make logistical arrangements to do the second set of activities, the interviews spanned into the growing season, which normally stretches from MidNovember to April. Frequency distribution of quantitative data was determined using Excel 2007 computer software. Data obtained from FGDs were scored and ranked.

\section{RESULTS AND DISCUSSION}

Constraints and coping strategies. The major constraints to crop productivity (Table $2)$ included rainfall variability $(\mathrm{CV}=0.30)$, shortage of inputs, low soil fertility, and crops damaged by elephants. Farmers ranked the constraints they faced in crop production according to the extent to which they affected food security and income generation. They also ranked the constraints according to the number of households affected and the extent to which livelihoods were impaired by these constraints. The constraints were of infrastructural, biophysical and socioeconomic nature.

Shortage of inputs. Shortage of planting seed, draft power, fertilisers and labour were common to both communal areas (Table 2). Approximately $60 \%$ of the interviewed farmers in each communal area cited shortage of planting seed; while shortage of draft power was cited by 50 and $25 \%$ of the farmers in Lower Gweru and Lupane, respectively. In Lower Gweru $75 \%$ of the farmers experienced shortage of fertiliser; while $30 \%$ of the farmers in Lupane faced the same problem. The problem of labour shortage, which surfaced in all wards during interviews, but was not mentioned during FGDs, was cited by about 67 and $20 \%$ of the farmers in Lower Gweru and Lupane, respectively.

Planting seed. Unavailability of planting seed, particularly hybrid seed, on Zimbabwe's formal markets, has been a problem only in recent years due to political and economic challenges. Over the years, it has been

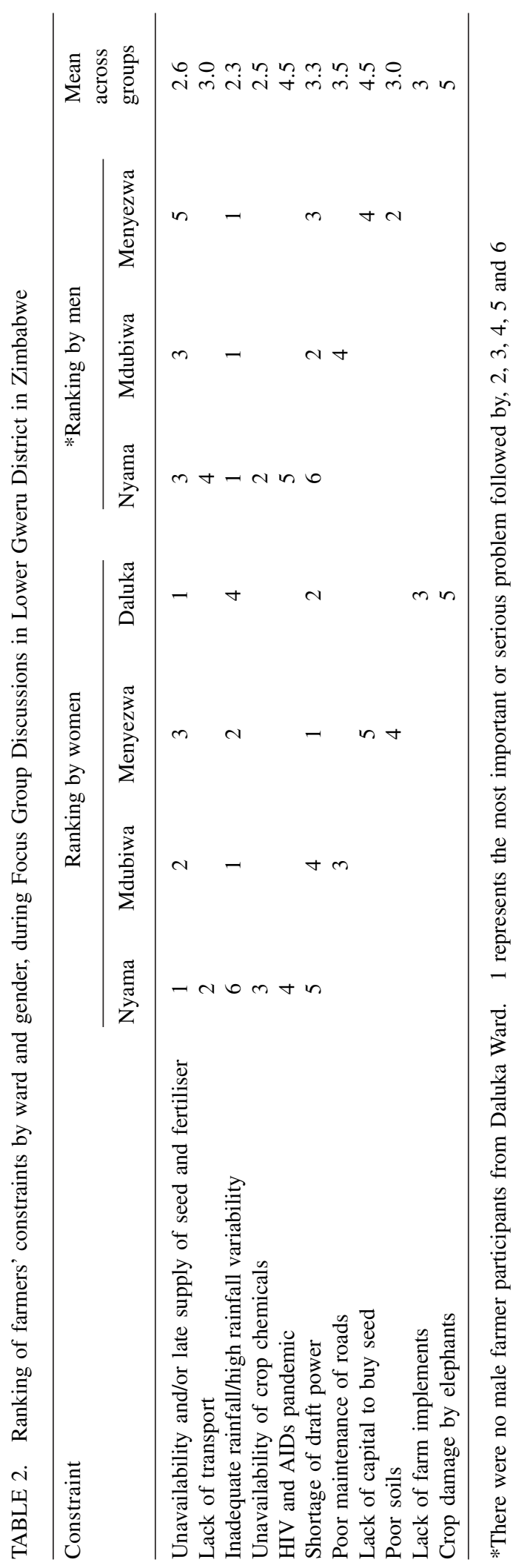


shortage of legume and improved small grains seed that has been a problem in communal areas (Shumba, 1983; Chuma et al., 2001). While sunflower was reported to be an important cash crop in western parts of the country (Ahmed et al., 1997), the crop was no longer grown by most farmers in Lupane and Lower Gweru during the study period, mainly due to seed shortage.

Farmers in both Lupane and Lower Gweru had maintained their traditional Open-Pollinated maize Varieties (OPVs) over the years. Use of these varieties alleviated the problem of shortage of hybrid maize seed, since these OPVs were readily and locally available. Farmers "trusted" these OPVs, which most believed yielded very well under high rainfall, but still gave reasonable yields when rainfall was low. In general, farmers retained seed even of hybrid varieties, from previous harvests to plant the following year. However, at times they were forced to consume the seed before the start of the subsequent cropping season, due to food shortages.

Drought relief programmes had in some seasons, for example 1994/95 and 1999/2000 seasons, provided farmers in these areas with some planting seed, particularly maize and small grain seed, as well as fertilisers. Recently introduced relief programmes, such as the "Maguta" and SADC input schemes which were introduced in 2005/06 and 2008/09 seasons, respectively, also provided farmers with groundnuts and cowpea planting seed, in addition to cereal grain seed (Mare, 2009 Department of AGRITEX - Personal Communication). However, these programmes, just like previous relief programmes, were characterised by late disbursement of inputs. Retention of seed by farmers in the study areas is a strategy that ensures availability of planting seed, although for hybrids, significant yield reductions occur with time, due to segregation of characteristics of the individual parental plants (Pixley and Bänziger, 2001; Tinsley, 2009). Farmers should, therefore, be encouraged to retain seed from previous harvests, particularly that of open pollinated varieties. They should be trained on effective techniques of storing seed to ensure freedom from pests and maintenance of high seed viability.

Fertilisers. Commercial fertilisers were relatively expensive (Table 2), rendering most of the smallholder farmers in the area unable to purchase adequate quantities. On the other hand, organic fertilisers such as cattle manure were often inadequate and of poor quality. The fertiliser shortage problem was compounded by the inherent poor soil fertility status of the land cultivated by these farmers. Thus, the problem of poor soil fertility reported in Menyezwa Ward (Lupane) was quite pertinent and consistent with findings of soil fertility studies carried out in most communal areas located in semi-arid Zimbabwe (Grant, 1981; Mashiringwani, 1983; Ncube et al., 2009), which concluded that low soil fertility and poor soil fertility management characterised these areas. To improve smallholder crop yields in these areas, sustainable soil fertility management strategies need to be put in place. These may include, among other practices, adoption of micro-dosing to make best use of the limited fertiliser resources, use of effective rotations that include nitrogen fixing species and practicing cereal-legume intercropping. Quality of animal manure in the communal areas also needs to be improved by providing appropriate bedding material and employing good compositing methods.

Draft animals. Draft animals provided about $70-90 \%$ of the draft power requirements of smallholder farmers in Zimbabwe (Norton, 1995; Chisango and Ajuruchukwu, 2010), so that in terms of policy intervention, draft animals (cattle and donkeys) and tillage implements such as ploughs need to be adequate for farmers in this sector. Shortage of draft power in communal areas of Zimbabwe is well recognised (Francis et al., 1999; Tsimba et al., 1999). The problem 
intensified following the severe drought of 1991/92 season, which killed many animals in the smallholder farming sector of the country. Farmers in the study areas also experienced shortage of draft implements as highlighted by the farmers in Daluka Ward (Table 2), further compounding delays in land preparation and crop establishment. These farmers coped by hiring and sharing draft animals and / or implements, exchanging labour for draft power and/or draft animals and by practising minimum or zero tillage. This was consistent with findings of Tsimba et al. (1999) and Wolmer and Scoones (2000).

Farmers also supplemented natural grazing with stover, when available; while others sent their animals to neighbouring commercial farms for grazing to keep draft animals in good condition. To alleviate farmers' problems of draft power shortage and lack of implements, agricultural extension efforts to promote tillage methods, which use less energy (for example minimum and zero tillage), should be intensified.

Zimbabwe Government and NGO programmes to rebuild the national cattle herd e.g. the Heifer International Project a project based on "pass on the gift" (of a heifer when a donated heifer has calved), should continue with improved momentum (Heifer International, 2014). There is dire need to promote indigenous cattle breeds, which are suitable in the study areas. The farmers should also invest in disease and parasites control and improve on livestock management practices such as animal housing, dosing and vaccination to ensure good health, high calving rates and reduced mortality rates (Tavirimirwa et al., 2013).

The District Development Fund, a public fund whose main objective is to develop rural areas (Zimbabwe Institute, 2005; Ministry of Finance and Economic Development, 2015) needs resuscitation as availability of tractors under this project has decreased over the years due to increased demand (CIMMYT, 2014), coupled with deterioration of the tractors and receipt of tillage services by non-targeted individuals and organisations at the expense of the targeted rural communities, communal farmers in particular (Ministry of Finance and Economic Development, 2015).

Labour. Labour shortage was mainly due to migration to urban areas (Table 2), and shift from farming by younger community members into other activities such as gold panning. Thus, labour was mostly family labour, comprising mainly of old people within the age range of 55 -75 years and school going children. Farmers in the study areas, particularly those in Lower Gweru, worked together in their fields, and sometimes assisted the less privileged members of the communities with operations such as land preparation, planting, weeding and harvesting. Labour is one of the factors that drive agricultural growth and development, in Africa (NEPAD, 2013), and as such labour shortage has policy implications on agricultural productivity in communal areas of Zimbabwe.

Labour shortages in crop production could be reduced by developing and employing innovations which are less labour intensive. For example, in weed management farmers should be encouraged to intercrop the staple cereal crops with legumes that provide good soil cover to suppress weeds (Mashingaidze, 2004). Use of cultivators to remove inter-row weeds and use of herbicides also reduce labour requirements for weeding (Chatizwa and Nazare, 2000; Obuo et al., 2003; Hossain, 2015). The practice of sharing labour and helping the less privileged to address labour shortage, is quite commendable and needs support from both the public and private sector.

Pesticides. Problems of shortage of pesticides to control insect pests and diseases, especially in vegetable crops; and transport for horticultural produce (e.g. tomatoes, leaf vegetables and fruits, mangoes in particular) to the markets were peculiar to Lower Gweru (Table 2). Pesticides were essential for high yield and good quality vegetable production. 
Lack of capital was the main contributing factor to shortage of pesticides. If not solved, these problems will lead to production and post-harvest losses, thereby impacting negatively on household incomes and food supplies. There is need for extension agencies and other stakeholders such as NGOs to assist farmers secure transport to ferry their produce.

Crop damage by elephants. The problem of crop damage by elephants was unique to Lupane (Table 2), as the area was in close proximity to the Hwange Game Reserve, as well as to the border with Botswana (Pfotenhauer, 2011; Government of Zimbabwe Ministry of Environment, Water and Climate. 2014). Although this problem was only reported by farmers in Daluka Ward during FGDs, about $50 \%$ of the farmers in both wards of Lupane highlighted the problem during household interviews. Farmers had no effective means of preventing crop damage by elephants, except to report to the personnel of the Department of National Parks, who they expected to take the animals back and keep them in game reserves. However, according to the affected farmers, for years, the Department had not done much to assist them. Farmers harvested crops as soon as they could to reduce the level of damage by the elephants.

HIV and AIDS pandemic. Farmers in Nyama Ward reported that the HIV and AIDs pandemic affected agricultural productivity (Table 2). The problem surfaced in FGDs, but not in household interviews, presumably because individuals were not free to mention this problem, lest they or their family members would be labeled as victims of the pandemic as most people were generally not willing to reveal their HIV/AIDS status. The effect of HIV and AIDS pandemic on agricultural production is two-fold; first is the reduction in capacity to invest in cropping due to health costs; and secondly is the reduction in labour supply (Zimbabwe Vulnerability Assessment
Committee, 2005).Thus, the pandemic has a negative effect on household food security in terms of food availability and utilisation components. To this effect, the spread of HIV/ AIDs needs to be curtailed through awareness campaigns. Early diagnosis and treatment of the condition will also go a long way in improving the health status of communities.

Rainfall variability. The problem of high rainfall variability was ranked highly by farmers in Nyama and Mdubiwa Wards (Lower Gweru) and Menyezwa (Lupane) Wards (Table 2). However, farmers in Daluka (Lupane) rated this problem fourth out of the five constraints they listed. Their reason for the low rating was that they did not have control on the rainfall amount or pattern as it was God-given . The response from Daluka farmers was consistent with the findings of Mertz et al. (2009) in rural Sahel, who worked on rural farmer perceptions of climate variability and change and observed that although farmers considered climate in decision making, they were rather generally defeatist about this factor as they could do nothing about it.

High inter- and intra-seasonal rainfall variability was not peculiar to these areas, but to Zimbabwe and southern Africa region as a whole (Hulme et al., 2001; Unganayi and Mason, 2001). Farmers in both study areas presented a wide array of rainfall-related problems. These included low rainfall amounts, short season lengths, late start of the season, abrupt end of the rainfall season, mid-season dry spells, excessive rainfall, rainfall unreliability especially with regard to start and end of season, as well as drought (Table 3.). The diverse rainfall patterns clearly indicated the awareness and sensitivity to the wide intra- and $\backslash$ inter-annual rainfall variability experienced in these areas. Poor crop yields, hunger, shortage of grazing, low animal productivity and weak draft animals were some of the direct impacts of the poor rainfall pattern and amount received in Lower Gweru and Lupane communal areas. 
TABLE 3. Strategies that smallholder farmers in Lower Gweru and Lupane communal areas of Zimbabwe use to cope and adapt to rainfall variability (Source: Focus group discussions and household interviews

\section{Driver of coping/adaptation Coping / Adaptive Strategies}

Low rainfall amounts

1. Winter plough to retain soil moisture; 2. Grow short duration crops \& varieties; 3 . Use of contour ridges; 4 . Concentrate on growing vegetables in gardens; 5 . Plant early; 6. Cultivate deeply; 7. Dry plant; 8 . Grow drought tolerant crops; 9 . Use planting basins (conservation farming); 10. Use less fertilizer; 11. Apply mulch (especially on planting basins)

Mid- season dry spells

1. Concentrate on growing vegetables in gardens; 2. "No plan"; 3. Use mulch; 4. Stagger planting dates; 5. Open up furrows to capture water; 7. Carry out cultural cleansing exercises e.g. clearing bushes of dead animal bones \& trees struck by lightning

Short season length

1. Grow short duration varieties/crops; 2 . Grow drought tolerant crops; 3 . Concentrate on gardening; 4. Early procurement of inputs + early land prep; 5 . Winter plough to retain moisture; 6. Dry plant; 7. Early plant; 8. Use less fertilizer

Late start of the rainfall season

1. Grow short season varieties/crops; 2. Concentrate on gardening; 3. Dry plant; 4. Grow drought tolerant crops; 5 . Conduct traditiona ceremonies such as "mukwerere"(beer brewing to appease ancestors) \& praying for rains

Abrupt end of rainfall season

1. Concentrate on gardening; 2. "No plan"

(Earlier than normal)

Extremely high rainfall

1. Apply more fertilizer if available; 2. Grow more sweet potatoes; 3. Grow more maize (in Lupane)

Waterlogging

1. Open up furrows to drain excess water (furrow drainage); 2. "No plan"

Crop failure, drought or hunger

1. Sell livestock to buy food \& get cash for other uses; 2. Buy items such as soap \& sugar \& exchange for maize grain; 3 . Get money to buy food from non-farming activities such as basket making, brick moulding\& gold panning; 4. Buy grain from the Grain

Marketing Board (GMB) if available; 5. Migrate to other areas; 6 . Get food aid from government \& NGOs; 7. Rely on remittances from children and/or relatives working locally or in Diaspora; 8 . Get assistance from local/community social groups; 9 . Reduce number of meals per day

Shortage of grazing

1. Supplement natural grazing with stover, if available; 2 . Take animals to neighbouring commercial farms for grazing

Weak draft animals

1. Rely more on donkey than oxen-draft; 2 . Reduce number of tillage operations; 3 . Supplement natural grazing with stover, if available 
Summer temperatures were also reported to be too high in some seasons, causing quick drying-out of the soil. Rainfall characteristics enumerated by the farmers in the study area indicated that rain-fed agriculture was unreliable and risky. Irrigation, breeding of drought and heat tolerant crops, staggered planting and in-situ water harvesting are some of the strategies that could be employed to reduce impacts of climate variability on crop production. Mulching was also recommended to reduce soil water loss from evaporation.

Farmers had a broad spectrum of strategies that they used to cope with rainfall variability (Table 3) and these can be grouped into crop and variety choice, choice of planting date, adjustment of crop input levels, soil water management, use of alternative sources of food or income and resorting to traditional and religious ceremonies. Some of these strategies were similar to findings by Mubaya (2010), in a study to establish adaptation strategies to climate variability in Zambia and Zimbabwe. The difference between the study/findings by Mubaya (2010) and the current study is that in the latter, farmers specified the rainfall variability problems and provided strategies they adopted for each. Choice of crop and planting date, as well as input level adjustment (especially with regard to amounts of fertiliser used), were the commonly used strategies.

Choice of crop and variety by farmers in the study areas supports findings from other researchers including Kurukulasuriya and Mendelsohn (2008), who showed that African farmers had adapted their crop choice to climate; and Salick and Byg (2007) who reported that indigenous people had used biodiversity to cushion themselves against environmental changes and disasters, over the years.

With the exception of use of contour ridges and winter ploughing, adoption of other soil moisture conservation techniques such as use of planting basins and mulch was fairly low due to limited labour and inadequate mulching material (Makuvaro et al., 2014). Winter ploughing conserves soil water (Kramer, 1997; Riches et al., 1998) as there are no weeds to transpire and use the water and was the major adaptation strategy to low rainfall that farmers used.

Farmers pointed out that in extreme cases of crop failure, they got external assistance in form of food hand-outs from the government and Non-governmental Organisations (NGOs), a strategy which is common in Zimbabwe (Munemo, 2008; Nangombe, 2014). They also relied on remittances from relatives working in urban areas or in the Diaspora. According to farmers in the study area, sale of livestock as an alternative source of income, was normally done when droughts and hunger were experienced. Kinsey et al. (1998), in their study on coping strategies for drought in Zimbabwe, concluded that this coping mechanism was consistent, contrary to the common belief that smallholder farmers in the country rarely dispose of their cattle but rather keep them for prestige as high cattle numbers was associated with wealth. The observation by Kinsey et al. (1998) perhaps illustrates that droughts are quite frequent and severe in Zimbabwe.

Inter-cropping and light pot-holing strategies were mentioned by only a few (about $5 \%$ of the farmers). Some farmers performed traditional ceremonies to appease ancestors and asked for rains and they also prayed for rains. About $30 \%$ of the farmers who responded to rainfall-related problems did very little, if anything, about mid-season dry spells and abrupt end of season. They simply had "no plan". However, some of the farmers responded to abrupt end of season by resorting to gardening and other non-farming activities, such as basket making and brick making (Table 3).

Staggering of planting dates and gardening were the two main strategies used to reduce the impacts of mid- season dry spells. Farmers resorted to small scale crop production, particularly vegetable production, in gardens as these (gardens) were normally located in 
areas with a high water table or close to water sources and where farmers may have dug wells or installed bore holes. This idea matches the findings by Thomas et al. (2007) that farmers try to gain access to land that gives good yields during times of drought. Some farmers believed that if bushes were not cleared of trees/bushes struck by lightning, severe mid-season dry spells would be experienced. To avoid these dry-spells, they held cleansing ceremonies to remove the lightstricken bones and trees.

Under high rainfall conditions, farmers tended to use higher fertiliser rates than they normally used, if the fertiliser was available. They also increased the area planted to crops that required high rainfall, for example sweet potatoes. In Lupane, where farmers generally grew more pearl millet and sorghum than maize, some farmers increased the area planted to maize when high rainfall was anticipated. It was pleasing to note that farmers used several coping and adaptation strategies to cope with high rainfall variability. These included appropriate choice of crops and varieties; adjusting levels of inputs used e.g fertiliser; staggering of planting dates; adoption of moisture conservation techniques (e.g. winter ploughing and mulching) and supplementation of natural grazing with stover. Researchers were, however, skeptical about traditional strategies such as removing trees stricken by lighting to avoid occurrence of severe midseason dry spells in the subsequent season. Many of the strategies the farmers used (for example growing of drought tolerant crops such as sorghum and pearl millet and staggering of planting) were technically sound and, therefore, need to be strengthened through more advocacy and ensuring availability of appropriate crop seeds. Government should invest more in irrigation development to combat the effects of high rainfall variability. We also recommend increased use of reliable seasonal rainfall forecasts by farmers, to help them employ the best crop production options in specific seasons. This would reduce the impact of high rainfall variability on crop yields.
Although strategies used by farmers in Lower Gweru and Lupane may be similar to those identified by other researchers for other countries, strategies such as off-farm diversification and intercropping were probably not as intensively practised in the study areas as they are practised elsewhere; for example in the Offin River Basin of Ghana, where most farmers diversify beyond farming (Gyampoh et al., 2009) and in West Africa where intercropping is a major adaptation strategy. Shifting away from reliance on agriculture as the main source of income and finding alternative sources of food are also important strategies for farmers in Malawi and Swaziland (Stringer et al., 2009). Farmers in the study areas and in other similar agro-ecological areas could also adopt or intensify such strategies. Intercropping for instance, is already being practised in Zimbabwe by smallholder farmers (Kamanga et al., 2003; Makuvaro et al., 2014), but needs intensification in terms of increasing its adoption and maximising soil and crop productivity under the system. Productivity can be increased by ensuring that farmers adopt the best known intercropping practices and through research. Diversification into nonagricultural income generation activities needs to be strengthened to broaden the food source of these rural communities.

\section{CONCLUSION}

This study documented constraints that smallholder farmers in semi-arid Western and Central Zimbabwe face in crop production and these range from bio-physical to socioeconomic challenges. Although the study revealed a plethora of constraints, it is encouraging to note that farmers in the study area had developed some level of resilience. Constraints faced by farmers included high rainfall variability; shortage of inputs; crop damage by elephants; HIV/AIDs pandemic; lack of farm implements and lack of transport for crop produce. The identified constraints provide entry points for stakeholder intervention, for improved food and nutrition 
security in semi-arid parts of the country. Coping and/or adaptation strategies used by farmers include use of seed retained from previous harvests, sharing draft animals and implements, working together in fields, choosing appropriate crops and varieties as well as planting date and adjusting input levels. These practices need to be reinforced and disseminated to other areas. The strategies used to deal with current climate variability for example choice of planting dates and crops, soil water conservation, regulating amount of fertiliser used and embarking on alternative non-agricultural sources of income are important as they could also address effects of the relatively long-term phenomenon of climate change.

\section{ACKNOWLEDGEMENT}

The authors are grateful to the International Research Centre for Development Climate Change and Adaptation in Africa (IDRC/CCAA) for funding the research activities (under project number 104144), Local authorities and AGRITEX officers in the study areas for logistical arrangements.

\section{REFERENCES}

Ahmed, M.M., Rohrbach, D.D., Gono, L.T., Mazhangara, E.P., Mugwira, L., Masendeke, D.D. and Alibaba, S. 1997. Soil fertility management in communal areas of Zimbabwe: Current practices, constraints and opportunities for change: Results of a diagnostic survey. Southern and Eastern Africa Region Working Paper no. 6, Bulawayo, Zimbabwe: International Crops Research Institute for the Semi-Arid Tropics (ICRISAT) Southern and Eastern Africa Region. 27pp.

Balnaves, M and Caputi, P. 2001. Introduction to quantitative research methods: An investigative approach. SAGE publications, London. Thousand Oaks, California. New Delhi, India. 267pp.
Bless, C. and Higson-Smith, C. 2000. Fundamentals of social research methods: An African perspective. $3^{\text {rd }}$ edition. Juta education (Pty) Ltd. 165pp.

Brewin, M., Majoor, H., Siwadi, P. and Seco, R.A. 2014. Operation evaluation: Zimbabwe, protracted relief and recovery operation 200453. Responding to humanitarian needs and strengthening resilience to food insecurity. September 2012 - March 2014. Final Evaluation Report. www.wfp.org/evaluation. Accessed 20 April 2017.

Chambers, R. 1994. The origins and practice of participatory rural appraisal. World Development, 22(7):953-969.

Chatizwa, I. and Nazare, R.M. 2000. Animal power for weed control: Experiences in Zimbabwe. In: Starkey, P. and Kaumbutho, P. (Eds). Animal power for weed control. A resource book of the Animal Traction Network for Eastern and Southern Africa (ATNESA) Harare, Zimbabwe: Intermediate Technology Publications, London. pp. 223228.

Chisango, F.F.T and Ajuruchukwu, O. 2010. Efficiency effects Zimbabwe's agricultural mechanization and fast track land reform Program. Paper presented at the Joint $3^{\text {rd }}$ African Association of Agricultural Economists (AAAE) and $48^{\text {th }}$ Agricultural Economists Association of South Africa (AEASA) Conference, Cape Town, South Africa, September 19-23, 2010. 23pp. http://ageconsearch.umn.edu/bitstream/ $97066 / 2 / 96 . \% 20$ Agricultural $\% 20$ mechanization\%20in\%20Zimbabwe.pdf

Chuma, E., Mvumi, B. and Nyagumbo. I. 2001. A review of sorghum and pearl millet - based production systems in the semiarid regions of Zimbabwe. SADC / ICRISAT Sorghum and Millet Improvement Program (SMIP), P.O Box 776, Bulawayo, Zimbabwe: International Crops Research Institute for the Semi-Arid Tropics (ICRISAT). 72pp. 
CIMMYT, 2014. Farm mechanization and conservation agriculture for sustainable intensification (facasi) project . Market analysis for small mechanizationZimbabwe. http://facasi.act-africa.org/file/ 20150130_market_analysis_for_small_ mechanization_zimbabwe.pdf Accessed 02/03/2017.

FAO (Food and Agricultural Organization of the United Nations). 2006. Zimbabwe's Natural Regions and farming systems. In: Fertilizer use by crop in Zimbabwe. Land and plant nutrition management service, Land and water devlopment Division Food and Agriculture Organization of the United Nations, Rome. 2006. ftp://ftp.fao.org/agl/ agll/docs/fertusezimbabwe.pdf (Accessed 10 June 2015).

Francis, J., Mudamburi, B. and Chikwanda, B. 1999. Animal draft power challenges in Zimbabwe. In: Starkey, P. and Kaumbutho, P. (Eds). Meeting the challenges of animal traction. A resource book of the Animal Traction Network for Eastern and Southern Africa (ATNESA), Harare, Zimbabwe: Intermediate Technology Publications, London. pp. 274-277.

Flick, U. 2006. An Introduction to Qualitative Research.Third Edition.Sage Publications. London. Thousand Oaks, California. New Delhi. 448pp.

Government of Zimbabwe Ministry of Environmental, Water and Climate. 2014. Hwange Sanyati Biodiversity Corridor (HSBC) project environment and social management framework February 2014. Waterkings Environment Consultancy. http://documents.worldbank.org/curated/ e n / $826991468335974436 / \mathrm{pdf}$ / E44740AFR00 ESM00Box382170B00 PUBLIC0.pdf Accessed 28/02/2017

Grant, P.M. 1981. The fertilization of sandy soils in peasant agriculture. Zimbabwe Agricultural Journal 78: 169 - 175.

Gyampoh, B.A., Amisah, S., Idinoba, M. and Nkem, J. 2009. Using traditional knowledge to cope with climate change in rur al Ghana. Unasylva 231/232 60: 70 74.

Harrell, M.C. and Bradley, M.A. 2009. Data collection methods:Semi-structured interviews and focus groups. Santa Monica, CA: RAND Corporation. http:// www.rand.org/content/dam/rand/pubs/ technical_reports/2009/RAND_TR718.pdf (Accessed 25 June 2015).

Heifer International, 2014. State of the African Farmer. Available at: http://fsg.afre. msu.edu/gisaia/AFRICA_140_State_ of_African_Farmers.pdf

HLPE, 2013. Investing in smallholder agriculture for food security. A report by the High Level Panel of Experts on Food Security and Nutrition of the Committee on World Food Security, Rome. http:// www.fao.org/fileadmin/user upload/hlpe/ hlpe_documents/HLPE_Reports/HLPEReport-6 Investing in smallholder agriculture.pdf Accessed 15 July 2015.

Hossain, M.M. 2015. Recent perspective of herbicide: Review of demand and adoption in world agriculture. Journal Bangladesh Agricultural University 13(1):19-30.

Hulme, M., Doherty, R., Ngara, T., New, M. and Lister, D. 2001. African climate change: 1900-2000. Climate Research 17:145 - 168.

Kamanga, B.C.G., Shamudzarira, $Z$ and Vaughan, C. 2003. On-farm legume experimentation to improve soil fertility in the Zimuto Communal Area, Zimbabwe: Farmer perceptions and feedback. Risk Management Working Paper Series 03/02. Harare, Zimbabwe: CIMMYT.

Kinsey, B., Burger, K. and Gunning, J.W. 1998. Coping with drought in Zimbabwe: Survey evidence on responses of rural smallholder farmers in semi-arid Zimbabwe: Transfers between Research and Extension. Proceedings of a National Technical Workshop, Masvingo, Zimbabwe. 3-7. April, 1995. pp. 106-117. Kramer, E. 1997. The early years: Extension services in peasnt agriculture in colonial 
Zimbabwe (1925-1929). Zambezi. xxiv(ii): 159-179. http://pdfproc.lib.msu.edu/?file=/ DMC/African\% $20 \mathrm{~J}$ ournals/pdfs/ Journal\%20of \%20the\%20University $\% 20$ of\%20Zimbabwe/vol24n2/juz02400 2005.pdf Accessed 24/02/2017.

Kurukulasuriya, P. and Mendelsohn, R. 2008. Crop switching as a strategy for adapting to climate change. African Journal of Agricultural Research 2(1): 105 - 126.

Makuvaro, V., Walker, S., Munodawafa, A., Masere, T.P., Murewi, C. and Chagonda, I. 2014. An overview of current agronomic practices of smallholder farmers in semiarid-Central and Western Zimbabwe. African Journal of Agricultural Research 9(35): 2710 - 2720.

Makuvaro, V. 2014. Impact of climate change on smallholder farming in Zimbabwe, using a modeling approach. $\mathrm{PhD}$, in Agricultural Meteorology. University of the Free State, Bloemfontein_South Africa.

Mare, V.K. 2009. Department of AGRITEX Personal Communication. Gweru District -Midlands Province, Zimbabwe.

Mashingaidze, A.B. 2004. Improving weed management and crop productivity in maize systems in Zimbabwe. PhD. Thesis. Department of Theoretical Production Ecology, Wageningen University. Wageningen. The Netherlands.

Mashiringwani, N.A. 1983. The present nutrient status of the soil in thecommunal lands of Zimbabwe. Zimbabwe Agricultural Journal 80:73 - 75.

Mertz, O., Mbow, C., Reenberg, A. and Diouf, A. 2009. Farmers' perceptions of climate change and agricultural adaptation strategies in ruralSahel. Environmental Management 43(5): 804 - 816.

Ministry of Finance and Economic Development, 2015. Report of the auditorgeneral for the financial year ended December 31, 2014 : Narrative report on appropriation accounts and miscellaneous funds. http://www.cabri-sbo.org/uploads/ files/Documents/zimbabwe_2014_ oversight_external_audit_report_ office_of_the_auditor_general_comesa_sadc_ english_1.pdf. Accessed 28/02/2017.

Mpandeli1, S. and Phokele Maponya, P. 2014. Constraints and challenges facing the small scale farmers in Limpopo Province, South Africa. Journal of Agricultural Science 6(4): 135-143.

Mubaya, C.P. 2010. Farmer strategies towards climate variability and change in Zimbabwe and Zambia: PhD Thesis. Faculty of Economic and Management Sciences, Centre for Development Support, University of the Free State, Bloemfontein_South Africa.

Mukasa, A.N., Simpasa, A.M. and Salami, A.O. 2017. Credit constraints and farm productivity: Micro-level evidence from smallholder farmers in Ethiopia, Working Paper Series N ${ }^{\circ} 247$, African Development Bank, Abidjan, Côte d'Ivoire.Ncube, B., Twomlow, S.J., Dimes, J.P., van Wijk, M.T. and Giller, K.E. 2009. Resource flows, crops and soil fertility management in smallholder farming systems in semi-arid Zimbabwe. Soil Use and Management 25: $78-90$.

Munemo, N. 2008. Political incumbency and drought relief in Africa. In: Barrientos, A. and Hulme, D. (Eds.). Social Protection for the poor and poorest: Concepts, policies and politics. Palgrave Macmillan, New York. pp. 264-281.

Munyanyi. W. 2012. Agricultural infrastructure developmentimperative for sustainable Food production: A Zimbabwean perspective. Russian Journal of Agricultural and Socio-Economic Sciences 12(24):13-24.

Nangombe, S.S. 2014. Drought conditions and management strategies in Zimbabwe. Available on: http://www.drought management.info/literature/UNWDPC_NDMP_Country_Report_Zimbabwe_ 2014.pdf. Accessed 23 February, 2017.

NEPAD, 2013. African agriculture, transformation and outlook. 72 p. http:// 
www.un.org/en/africa/osaa/pdf/pubs/ 2013africanagricultures.pdf Accessed 20 / 02/2017.

Norton, A. 1995. Soil and water conservation for smallholder farmers: Past, present and future. In:Twomlow, S., Jones, J.E, Hagman, J. and Loos, H. (Eds.). Soil and water conservation for smallholder farmers in Semi- arid Zimbabwe: Transfer between research and extension. Proceedings of a Technical Workshop, Masvingo, Zimbabwe 3-7April 1995, pp. 5 - 21.

Nyamapfene, K.W. 1991. Soils of Zimbabwe. Nehanda Publishers, Harare, Zimbabwe. $179 \mathrm{pp}$.

Obuo, J.E.P., Agobe, F., Oryokot, J. and Barton, D. 2003. Weed management in groundnuts using ox-drawn weeders in northeastern Uganda: Farmers experience in ox-drawn weeders. African Crop Science Conference Proceedings 6:161166.

Pfotenhauer, 1. 2011. Elephants Without Borders: A Reprint from Peolwane, the Air Botswana Magazine, September 2007 Issue, Imprint Botswana. http://elephantswithout borders.org/downloadspapers/EW B inPeolowaneSep07.pdf

Pixley, K. and Bänziger, M. 2001. Openpollinated maize varieties: A backward step or valuable option for farmers? In: Friesen, D.K. and Palmer, A.F.E. (Eds.). Seventh Eastern and Southern Africa Regional Maize Conference proceedings, $11^{\text {th }}-16^{\text {th }}$ February, 2001, pp. 22-28.

Riches, C.R, Ellis-Jones, J., Twomlow, S.J., Mazhangara, E., Dhilwayo, H., Mabasa, S. and Chatizwa, I. 1998. Participatory development of tillage/weed management practices for maize farmers in semi-arid Zimbabwe: Who benefits? In: Participatory development of tillage/weed management practices for maize farmers in semi-arid Zimbabwe. Who benefits? Rural Livelihoods, empowerment and the environment: Going beyond the farm Boundary. $15^{\text {th }}$ International symposium of the Association of Farming Systems Research - Extension. 29 November - 4 December 1998, Pretoria. 3:1480-1488.

Salick, J. and Byg, A. 2007. Indigenous peoples and climate change. Oxford, UK, Tindall Centre for Climate Research. http:/ Lzimbabweland.net/Zimbabwe\%27s\%20 Land\%20Reform\%20Booklet\%20Web.pdf (Accessed 20 July 2015.

Scoones, I., Marongwe, N., Mavedzenge, B., Murimbarimba, F. Mahenehene, J. and Sukume, C. 2011. Zimbabwe's Land Reform: A summary of findings. IDS: Brighton. http://zimbabwe land.net/ Zimbabwe's\%20 Land\%20Reform\%20 Booklet\%20Web.pdf Accessed 23/02/ 2017.

Shiferaw, B. 2006. Poverty and natural Resource management in Semi-Arid Tropics: Revisiting challenges and Conceptual issues. Journal of Semi-Arid Tropics (SAT) Agricultural Research. 2(1): 1 - 21. http://ejournal.icrisat.org/mpii/v2i1/ v2i1poverty.pdf (Accessed 15 July 2015).

Shumba, E. 1983. Factors contributing to a decline in groundnut production in the Mangwende-Murewa district and the need for a technical research input. Zimbabwe Agricultural Journal 80:251 - 254.

Stringer, L.C., Dyer, J.C., Reed, M.S., Dougill, A.J., Twyman, C. and Mkwambisi, D. 2009. Adaptations to climate change, drought and desertification: Local insights to enhance policy in southern Africa. Environmental Science Policy 12(7):748 765.

Sutherland, A. 1998. Participatory research in natural resources. Socio-economic Methodologies Best Practice Guidelines. Chatham, UK: Natural Resources Institute. Available on: http://www.f ao.org/docs/ eims/upload/agrotech/1911/BP G03.pdf. Accessed 17 June 2015.

Tavirimirwa, B., Mwembe, R., Ngulube, B., Banana, N.Y.D., Nyamushamba, G. B., Ncube, S and Nkomboni, D. 2013. Communal cattle production in Zimbabwe: 
A review. Livestock Research for Rural Development. 25, 217. http://www.lrrd. org/lrrd25/12/tavi25217.htm Accessed 08/ 03/2017.

Thomas, D.S.G., Twyman, C., Osbahr, H. and Hewitson, B. 2007. Adaptation toclimate change and variability: Farmer responses to intra- seasonal precipitation trends in South Africa. Climate Change 83(3):301 322.

Tinsley, R.L. 2009. Post harvest handling and seed quality evaluation for selected value chain commodities in Nigeria. 61pp. http:/ /webdoc.agsci. colostate.edu/smallholder agriculture/WASANigeria.pdf Accessed 28/ 02/2017

Tsimba, S., Chawatama, R., Ndlovu, L.R., Mutimba, J., Ndhovu, P., Dzama, K.,Topps, J.H., Hawk, D. and Mudhara, M. 1999. Socio- economic aspects of draft power: A diagnostic study in Zimbabwe. In: Starkey, P. and Kaumbutho, P. (Eds.). Meeting the challenges of animal traction, A resource book of the Animal Traction Network for Eastern and Southern Africa (ATNESA). Harare, Zimbabwe. Intermediate Technology Publications, London.
Uddin, M.N., Bokelmann, W. and Entsminger, J.S. 2014. Factors affecting farmers' adaptation strategies to environmental degradation and climate change effects: A farm level study in Bangladesh. Climate 2:223-241.

Unganayi, S.L. and Mason, S.J. 2001. Spatial characterization of Zimbabwe summer rainfall during the eriod 1920-1996. South African Journal of Science 97: 425 - 431.

Wolmer, W. and Scoones, I. 2000. The science of "civilized" agriculture: The mixed farming discourse in Zimbabwe. African Affairs 99: 575-600.

World Bank, 2008. Agriculture for Development. World Development Report 2008. Available on: https://siteresources. worldbank.org/INTWDR2008/Resources/ WDR_00_book.pdf Accessed 26 February, 2017.

Zimbabwe Vulnerability Assessment Committee. 2005. ZimbabweLivelihood Profiles. www.fews.net/livelihood/zw/ National.pdf. Accessed 26 May 2012).

Zimbabwe Institute, 2005. Local Government: Policy Review. Capetown, South Africa. Available at: http://www.zimbabweinstitute. net/File_Uploads/docs/Local_Government_ Paper.pdf Accessed 28/02/2017. 